\title{
Job Insecurity Affects the Employee Performance with, Mediating Role of Turnover Intention: A Case of Highnoon Pharmaceutical Company Pvt Ltd
}

\author{
Hamid Mahmood \\ $\mathrm{PhD}$ Scholar \\ University of Sultan Zainal Abidin (UniSZA), \\ Malaysia
}

\author{
Abdul Rauf \\ Student \\ Department of Management Sciences \\ Arid Agriculture University, Pakistan
}

\begin{abstract}
The objective of this paper to investigate the impact of job insecurity on employee performance with the mediating role of turnover intention. It will help the Highnoon laboratories to develop the roadmap to provide different strategies, increase employee performance and decrease turnover. Quantitative research approach used in this study and data has been collected through survey research method in which adopted questionnaire will use as instrument of the survey. Target population of this study-will be employee of the Highnoon laboratories. Research data has been analyzed by applying descriptive statistical techniques through SPSS(v 21.0) software. Descriptive statistics, diagrams, standard equation method, SEM correlation, and linear regression tests have been applied to draw the results of the study.
\end{abstract}

Keyword: Job insecurity, employee performance, turnover intention,

\section{INTRODUCTION}

Performance

The study shows the effect of decision making on employee performance (Motowidlo, 2012) to add value to the related performance. Related performance can influence in taking a decision regarding the efficiency of employee performance and it can also influence the decision of the seniors either he would consider his employee for the promotion or not. If the performance of the employee is good and in a positive way it will be related to the higher job satisfaction. Therefore the study investigate performance on a large level with practical's and also with theories related performance (Bormen, 2013).
A single aspect which indicates the serious association aimed at the job and performance of the employee. There is a clear statement regarding the relations by (Hackman, 2011) lay the groundwork for creating a job design from theory regarding expectations. That introductory job design, motivate the worker to do hard work and enhance the firms goal and employees need, it is also developed by (Oldham, 2016). Previous studies regarding their job components, said that all the results, in laying the efficiency of the performance, predicted much beneficial for job throw motivations along huge work.

Basically, employee performance refers to the task achieved and completion of the work Performance belongs to keeping plan up to date to get desirable results, despite, performance evaluation in human resource management (Cardy, 2004). Performance of the employee and organization is depended on organizational practices, design features, and policies of the organization.

This combination represents the configurable approach of the strategies of human resource department. Every single act to achieve organizational goals,(Delery, 2001). High employee performance refers to the key engagement of the employee. It is also shown in the past studies (Mone, 2010). Different studies mention the impact of engagement on the employee performance, there are a number of the instrument which can use to measure that impact among them.

(Harrison, 2006) highlight the job performance and job attitude in different studies. In past studies 
employee, engagement and performance are key factors (Bakker, 2008). Research linking the evidence with employee performance, employee engagement and turnover, managers also think engagement of employee is very beneficial for the organization (Attridge, 2009). Studies also show that employee engagement and employee performance is very important to achieve a desirable result for the organization.

\section{Job insecurity}

Job insecurity appears from workers perception about events, signal link with work, people and social atmosphere. Employees have a negative perception about job insecurity when new managers arrive (Kim, 2017). Out of way efforts from the company make workers think to have risk job loss in future. Normally in a single industry, feeling of getting job insecurity increase. Employee's assessments for job insecurity suppose job insecurity condition in the organization. Job insecurity can threaten individual's personal resources and identity (Shoss, 2017). A few years back, due to the world, economic restructuring labor market is modified.

In the increase of feelings of job insecurity effected number of employees (Callea, 2012). Previously change in business climate has forcefully arisen the perception regarding job insecurity. Organization achieving their goal with limited resources provided by the organization. Uncertain economic condition and increasing competition led to the mergers, acquisitions, and different structural changes, finally induce the job insecurity feelings in the employees will rush with the job insecurity and feelings of continuing jobs in future (Burke, 2007).

In present society, job insecurity is an important concern. International challenges are increasing day by day and competitions are increasing the standard of the organizations (e.g. downsizing, mergers, acquisitions, plant closings). In some countries, reforms regarding labor regulation have an increase in short-lived employees, and in the public sectors also (ESC, 2007). In the same context, many of the workers claim that contributing one's whole life working in the same organization is the past thing (Eurobarometer, 2006). With these statements, a number of employees worried to lose their job in future (ISSP, 2005).
Job insecurity becomes continue phenomena that link with organizational success and utilization of resources effectively. Seniors are resist to mess job insecurity with the organizational goals. Researchers must have to give solution for this problem (Lee, 1997) different organizational literature give importance to the job insecurity intention to losing a job, work stress, disqualification, organizational commitment. This social behavior proves that job insecurity affects the performance (Rub, 2004).

That's why studies aim to enhance research on attitude responses about job insecurity. Researcher grasps two type of performance turnover, extra-role attitude and task. After it, organizational consumer behavior is very important to support organizational performance. (Dalal, 2005). By taking as performance, it extends over emotional and behavioral importance which mostly affects the job insecurity (Svrek, 2002).

\section{Turnover}

In the study, we target the hazards in the turnover of the employee for the organization. (Telford, 2007). Discussed that after the earthquake in Indian ocean and tsunami high level of employee turnover could inhibit to help in disaster activities. In human logistic field identification of employee turnover should be an important component which effects the logistic affairs and recent research (Korff, 2015). Advised that worker turnover in human organizations have a primal problem. In the organizational study, employee turnover, attract the attention regarding dissatisfactory work (Grant, 2012). That's why, fewer studies regarding employee turnover, and very difficult to understand human organization in that context. The aim of the study to explore the reasons affecting employee turnover regarding the human organization.

A number of researchers trying to get the answer from possible examples of what foster the employee turnover. This wise interest comes from noticing that turnover could be costly, and we can get huge benefits by managing and understanding it. Initial studies give good support to intent as a solid philosophy about actual turnover (Tett, 2009). It objective to leaves the conscious wish to left the organization in near future, at the end process to regard withdrawal process (Mobley, 1989). A media release by (Steel, 1994) determine that intent to leave is a better prognosticator of real turnover attitude than impacting variable, like as total job satisfaction and also satisfaction with 
work. However, it will be a crucial concern to learn about the cause of turnover intention in the future turnover intention.

Unsuitable work condition is a basic reason employee leave organization (Jung, 2012). It is very important to understand turn over the intention of the employee to improve business, invest train and recruit new employee high turnover is very important (Chen, 2011). Past studies cite many presences of turnover intention of employee, like a limited job (Dysvik, 2013), low commitment of organization (Yousaf, 2015), and poor pay perception process of decision making. Another noticeable reason for frustration is providing less information about rules and regulation of the organization which creates an uncertain condition for the employee to continue his job (Schmidt, 2014). Such negative role impose employee to leave the organization, but past studies only offer direct effect on work outcomes and turnover intention especially (Wang, 2014).

In the work organizations, employee turnover intention is very important managerial concern (Pfeffer, 2006). It is very costly to replace an employee, it takes time to recruit or train an employee to get satisfactory results (Collins, 2006). High employee turnover might slow the consistency, stability, and quality of services which organization offer (Trevor, 2010). And increase turn may cause dissatisfactions with the organization.

\section{Problem statement}

There is different effect of job insecurity on employee performance in different organizations, the significant difference is just because of different strategies of the organization and core objectives of the organizations (Gran, 2015) and it has influence impact on turnover intention. Newly hire people employee as well as an old employee who have job insecurity their performance effect by the threat which leads to the influence in turnover intention.

\section{Research objectives}

$>$ To determine the relationship between job insecurity and employee performance.

$>$ To evaluate the relationship between job insecurity and turnover intention.

$>$ To find out the relationship between turnover intention and employee performance.

\section{Research questions}

$>$ Do job insecurity impact on employee performance.

$>$ To what extent how job insecurity impact on turnover intention.

What is the mediating effect of turnover intention on employee performance.

\section{Scope of study}

The present study investigated the impact of job insecurity on employee performance with the mediating role of turnover intention. So the study conducted on Highnoon laboratories. Targeting population is the employee of the organization who has job insecurity. Scope of study is limited due to the signal organization from which data has collected the study and its objective was very helpful for the organization.

\section{Significance of the study}

The present study investigates the impact or relationship between the variables. This study will helpful for the organization in a different aspect because employee performance is very important for an organization, so this study with the practical and theoretical point of view will help the organization for their employee performance.

However, if we promote the use of new ideas which is favorable for the organization, then the organization can give job insecurity to their employee to increase performance and turnover intention. Due to lack of confidence on job and organization employee become offended.

\section{Literature view}

\section{Employee performance}

Job performance could be explained as attitude or act by the worker at the individual level (Campbell, 2016). Wrangle that performance of the job was the essential outcome of self-evaluation every one with high self-evaluation was motivated for their job performance. By increasing confidence and skills they can perform better. Self-evaluation directly related to the job satisfaction and the performance of individuals. Many researchers espouse the concept of individual performance and approved the worker's performance relationship with multiple variables (Lentz, 2009). Search that career plan decrease job performance significantly (Morrow, 2012). Argue that redesign of the job also influences the employee behavior and Highnoon laboratories commitment. 
Previous studies also inspect the performance of the worker in relation to Highnoon laboratories outcome productivity and growth (Ubeda, 2013).

A number of studies try to increase understanding of variables in task performance has focused on the informative concept that force relatively contracted forms of worker selves. Philosopher has Gestate himself in physical energy that could be allotted in the different task and non task territory according to classify individual for them to roles they have (Ashforth, 2008). Job involvement concept refers the scope in which worker close to their job as involving their lives, There for an employee who displays job involvement strongly with their job and thought about their job even outside of the work (Kanungo, 2010). Job involvement impact by Highnoon characteristics, seniors behavior, and personal differences (Brown, 1996). And job performance due to every single employee who select their job focus on work and delay position as an opportunity for performance (Hillman, 2008).

Another branch of the work, consist of almost narrow narrations of self-research, it connected with the emotional reactions of the employee with directly associated with human wishes to fill individual psychological wants and values. There are huge studies on the job satisfaction, which indicate to positive emotional resulting from individuals job experience (Locke, 2016). Job satisfaction could be promoted via the positive approach of job aspect, seniors, and labors (Russell, 2004). also impact by various individual personality (Judge, 2017). Favorable feeling relates to the satisfaction of the job that results in positive estimations what the Highnoon supplies make crowd willing to hoist the attitude related to the task that ante up Highnoon effectiveness (Bono, 2017).

There was a much experimental support for the argument by (Eden, 1993). Prove the valid source of feedback, they would predict with honest leaders and raise efficacy many good researchers (Detert, 2010). Good leadership increases the performance on large scope via modeling that looks like a knowledgeable tool. In simple words, by observing their managers workers learned to perform their job best (Mitchell, 2010). Thus improve the perception of selfperformance.

\section{Job insecurity}

Job insecurity can explain as uncertainty which feels by the employee that he can continue his job in the same position in future (Witte, 2015). It was a general perception created from the assessment of real work environment. Therefore, the same situation might have a different perception of contingency for different workers. There was solid evidence that proves insecurity in the job has a negative impact on the attitude and health of the employee. Therefore, limited studies have investigated the behavioral importance and understanding of the system and argue that with job insecurity performance outcomes was decrease. Work performance territory initially refers to the scope of work and dependent performance (Borman, 2001). Task performance can describe an attitude that directly participates in the Highnoon professional core and consider the end nonmandatory of work attitude. By comparison, important and extra-role performance was compiled with the effort that anyone goes beyond the requirements of the organization.

Social theories suggest that communication regarding job insecurity with the employees have negative impact on their status and expectations with the firm, it was frustration of the employee being valuable member of the organization, in reality job insecurity can define as perception of involuntary undesired change and in the continuity of the job (Sverke, 2004). Therefore, it looks reasonable to predict that employees do not feel them an important part of the organization due to job insecurity, because employees worried to being terminated (Piccoli, 2017).

Especially, it happened in the reaction on the threat to need acceptance, involvement, and appreciation. Employee assimilation with the firm also satisfy the employee needs, which developed the impression of membership, on another hand, frustration regarding this thing in the employee care about individuals how they were part of organization, situation did not full fill the membership need where an employee feels his job insecure, because employees who afraid about future regarding their job to have a good position in organization or being very low status in the group (Van, 2004).

As argue in the theories, extra demand or poor resources in a particular territory or area or among the territories have an adverse effect and debilitated attitude (Shaffer, 2001). It suggests the adverse 
linkage amid turnover and job insecurity. It normally happened, when sale people feel the risk of future and threats to their job and resources, they address the job dissatisfaction, unfavorable turnover and poor performance. After all, there was evidence that proves job insecurity scour the job satisfaction (Cheng, 2008). Studies provide prove the negative relationship aimed job satisfaction and the job insecurity (Vujicic, 2015). Documented that job satisfaction reduced due to job insecurity. Studies determined that job insecurity feeling weak the job satisfaction and reduce the performance (Vander, 2014), and also establish the same findings aimed two variables.

Many researchers refer that threat to the job loss and discontinuity of the job in the future (Ferrie, 1993). Other Describe that job insecurity was a threat of individual for job continuity in the future, and also continuity of particular features of the job, promotion, and expectation of promotions, depend on past explanations, job insecurity composes both desirable features of job and losing a job (Greenhalgh, 1998). Explain job insecurity as powerlessness to preserve the continuity in scare job situation. Although (Joelson, 2005) argue that job insecurity as employee assessment of the possible threat of discontinuity of current job, Highlight the real difference aimed job insecurity, unemployment or job loss. After it, some authors explain it as a real threat to the current job in continuity, and some explanation as individual experience of a basic involuntary act refers to the job loss. Job insecurity could experienced at the individual level or refers to an external position like the uncertainty of employment in future (Sverk, 2008).

\section{Turnover Intention}

Managers affect turnover throw big framework of personal motivation. Past studies show that employees who work in public sector were less plan to leave job when they were a great level of involvement in job and innate motivation (Bertelli, 2007). They satisfy with the opportunities for improvement, when they have a variety of good policies (Moynihan, 2011), and when have trust on their seniors (Davies, 2016). They found that factual work in turnover of the public sector, depending on the survey, and data about employees motive. Supervisors, have more interest in a turnover rather than turnover intention and proceed that decline intention might not have the same effect on turnover. Although expanding evidence express that alertness carries many benefits, studies investigate that alertness from the workplace can increase turnover. Turnover intention and job satisfaction associated with two domains (Vogus, 2011).

High commitments in human resource management practices were very important, merit, hiring, performance, turnover (Macky, 2007) selection of qualified employees can increase turnover, and hiring a good person on merit base can increase turnover, and job satisfaction boosts up the performance and firm commitment (Williams, 2009). Accurate system and performance system reduce turnover intention. In another hand, intangible and tangible rewards can also boost the performance and turnover. Injustice in the system has negative impact on turnover because workers express their feelings and raise their voice throw system instead of exit the job. A good system can reduce the turnover intention by improving the distribution of justice and satisfaction about work in the employees (Haines, 2010).

Turnover of the employee refers to the completion of a psychological and official contract between an organization and employee (Macdonald, 2003). Employee turnover have two basic types, voluntary and involuntary, voluntary turnover was initially proposed by the worker himself, whereas involuntary turnover proposes by the organization to cancel the relation with employee (Cao, 2013). In the studies, turnover intention mostly used to predict the turnover at workplace . Aim to quit, time to leave, turnover intention and aim to left were mostly used reciprocally. However, the turnover intention was not necessary to link employee turnover, strongly predict about turnover behavior refers to the turnover intention, by past studies, the relationship among turnover intention and employee performance was confirmed (Bluedorn, 1997).

Turnover rates increase organization cost, normally when organization found a trained employee

(Youngblood, 1993). Turnover intention captures the employee mind to leave the organization himself (Chan, 2011), and significantly procure real turnover (Horner, 1991). Although actual turnover attitude also reflects outside industrial. So turnover intention explained rather than attitude, was most helpful for analyzing how inside factor impact turnover, which was very important for firm effectiveness. 


\section{Theoretical Framework}

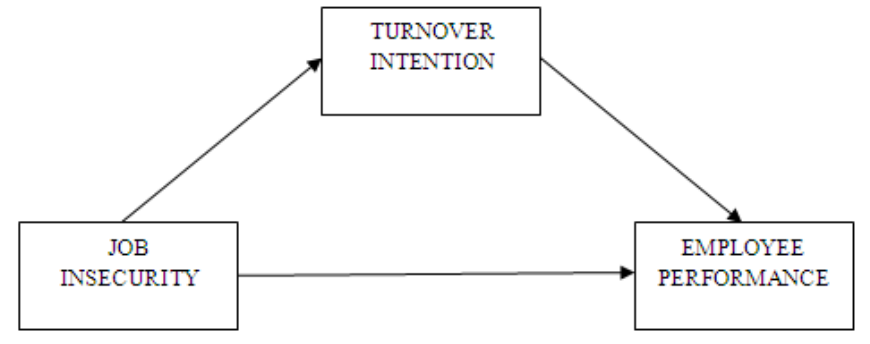

\section{Hypothesis}

$>$ There is a significant relationship between job insecurity and employee performance.

$>$ There is a significant relationship between job insecurity and turnover intention.

$>$ There is a significant relationship between turnover intention and employee performance.

\section{Methodology}

Ontological assumption is the reality of things and it is based on objectivism (Smith, 2017). Epistemological assumption is the relationship between research and being researched and it is based on objectivity (Cambell, 2015). This study has been conducted to examine the impact of job insecurity on employee performance by the mediating role of turnover intention. For this purpose, this study has been using the positivism approach for testing the theory in deduction and survey method has been used to collect data with the adapted Lickert scale questionnaire. Area of study has chosen pharma sector of Lahore, Karachi and Multan in Pakistan for testing this theory.

\section{Research approach}

This research was used quantitative approach in research methodology. In Quantitative, research organized data on the numerical procedure or that can approximately translate into number (Ross, 2017). It is well-ordered, particular methodology to research. Quantitative research was used the simple random technique. The neutral of quantitative research is to develop and use calculated models, philosophies and guesses concerning to natural phenomena. The progression of quantity is essential to quantitative research as it delivers the necessary joining amongst empirical reflection and mathematical manifestation of quantitative interactions. It apprehensive with statistics and whatever, which is reasonable. Calculating and computing are mutual forms of quantitative approaches.

\section{Sampling techniques}

The marked population of this study was contained of employees and managers of Pharma sectors from Lahore Multan and Karachi. The unit of analysis was used who is working in Pharma sectors and test them mutual rather than separately. The sampling frame was used related to probability from employees and managers working employees both old and fresh in these sectors in Pakistan of Multan Lahore and Karachi. In addition, their responders were chosen randomly because every unit of analysis in probability technique has equal chances of selecting. Here is the questionnaire filled by hand and performed practically a survey of investigation.

\section{Sample size}

There is sample size for this research was based on the 15 item of questionnaire multiply by 10 which were made 150 sample sizes. So we collect the data 150 employees of these Pharma sectors randomly by using simple random technique from probability sampling.

\section{Data collection method}

The data has been collected from Highnoon laboratories separately from Lahore, Multan and Karachi areas due to the shortage of time. The researcher distributes the adapted questionnaires to the responders by himself and by hand. The researcher did give them a questionnaire in hard form and receive after one week from initial time. The researcher used a five-point Likert scale because this scale easily understandable for every employee and also used in previous studies. 150 questionnaires have been collected out of 178 from the employees.

\section{Data analysis}

SPSS 21.0 version has been used for descriptive and inferential statistics. Reliability of model has tested with Cronbach's alpha and validity has been checked with factors analysis. According to Hayes and Preacher in which we run the simple linear and multiple regression analysis with interaction term for testing mediating effect (Hayes, 2014) .

\section{Validity test}

Validity is the strong point of our deductions, suggestions or proposals. More officially (Cool, 2017) define it is as the 'best available approximation to the truth or falsity of a given inference, proposition or conclusion' the validity of a scale may be welldefined as the range to which different in observing 
scale scores reflected true alterations among objectives on the most distinctive being measured, rather than systematic or stratified error. There are two core things that essential to get the validity testing, that are content validity and construct validity and all other types are less important but important (Winter, 2000).

As the questionnaire is self-conducted, the validity test should be conducted. The researcher uses SPSS 21.0 to test the validity of questionnaire and 280 respondents from the target population have been to assess the questionnaire from Pharma sectors.

\section{Reliability test}

Reliability would be evaluated by internal consistency and it can be measured in a numeral of ways. The most common form used statistics in Chronbach's Alpha. These statistics provide an indication of the average correlation among all of the items that make up the scale. While different levels of reliability are required, depend on nature and purpose of the scale, (Nunnally, 2017) recommends a minimum level of 0.7 Chronbach's Alpha is defined as where is the number of components (k-items or testlests), the variance of the observed total test scores, the variance of component of the current sample of person (Develles, 2016) .A commonly accepted rule of thumb for describing internal consistency using Cronbach's Alpha.

\section{Findings \\ Reliability Analysis}

To check reliability of data, consistency analysis using Cronbach's alpha $(\alpha)$ method has been done using SPSS. Reliability analysis is used to measure the internal consistency of the collected data and it ranges from $0-1$. Cronbach's alpha $(\alpha)$ has been calculated to check for reliability analysis. It is assumed that the closer the value of Cronbach's alpha coefficient to 1 , the greater the internal consistency of data. George and Mallery (2003) provides a rule of thumb: " $\alpha>0.90$ - excellent, $\alpha>0.80$ - good, $\alpha>$ 0.70 - acceptable, $\alpha>0.60$ - questionable, $\alpha>0.50$ poor, and $\alpha<0.50$ - unacceptable". Moreover, the value of Cronbach's alpha $(\alpha)$ also depends upon the number of items/questions in the scale. It must be illustrated here that with the increase in number of questions, the reliability in factors will be low.

\begin{tabular}{|c|c|}
\hline Factor & Cronbach's Alpha $(\alpha)$ \\
\hline Job insecurity & 0.71 \\
\hline Turnover Intention & 0.84 \\
\hline Employee Performance & 0.76 \\
\hline
\end{tabular}

All the constructs used in this study demonstrate the acceptable values of Cronbach's alpha $(\alpha)$ as evident from table. It shows consistency in our collected data. Cronbach's alpha $(\alpha)$ scores with values of $0.71,0.84$ and 0.76 respectively. However, turnover intention factors with higher values comparatively employee performance.

\section{Regression Analysis}

Statistical analysis was performed on empirical data to derive results. Multiple regression analysis and correlation analysis was employed. Based on these analyses, the developed hypotheses were tested and research questions were answered.

\section{Testing of Hypotheses}

After data collection, the regression analysis has been done to estimate the results. Here, particularly multiple regression approach was followed. Table presents the findings from regression analysis, where $\beta$ values are regression coefficients and t-values are used to decide the significance of study. According to rule of thumb, t-value greater than $2(>2)$ is considered as significant and used for decision making of developed hypotheses.

\begin{tabular}{|c|c|c|c|c|c|}
\hline \multicolumn{7}{|c|}{ Estimates of regression parameters and their t-values } \\
Factors & Hypotheses & Beta $(\boldsymbol{\beta})$ & $\begin{array}{c}\text { Causal Relationship with } \\
\text { Consumer Resistance }\end{array}$ & t-value & Significance \\
\hline Job Insecurity & H1 & 0.19 & Positive & 1.04 & Significant \\
\hline Turnover Intention & H2 & 0.12 & Positive & 4.81 & Significant \\
\hline Employee Performance & H3 & 0.39 & Positive & 3.08 & Significant \\
\hline
\end{tabular}

The table shows that hypotheses $\mathrm{H} 1$ i.e. Job Insecurity, $\mathrm{H} 2$ i.e. Turnover Intention and $\mathrm{H} 3$ i.e. Employee Performance are supported. The obtained positive correlation between Job Insecurity and Employee performance is also contradicted with model used by Park \& Chen (2007) and Amin (2008). 
The hypothesis of Job Insecurity i.e. H1 was also supported which described that employee performance are compatible with organization. Similarly, the support for $\mathrm{H} 2$ i.e. turnover intention and $\mathrm{H} 3$ i.e. outsourcing are also in accordance with previous findings (Laukkanen et al., 2007; Yiu Chi et al., 2007) that have found that job insecurity and employee performance has a positive and substantial impact. So, respondents who feel that turnover intention have a positive significant impact on employee performance.

\section{Factors Interrelationships (Correlation)}

The correlations among the hypothesized factors have been derived. We have different correlation results from previous studies. Relative advantage has been found as positively correlated. Respondents who want more benefits were also more concerned about having job insecurity associated with employee and they also prefer a trial-based job. Table shows the correlation values of all factors, demonstrating direction and strength of relationships between variables.

\begin{tabular}{|c|c|c|c|}
\hline \multicolumn{4}{|c|}{ Factors Interrelationships } \\
\hline & JI & TI & EP \\
\hline JI & 1.000 & -- & -- \\
\hline TI & 0.531 & 1.000 & -- \\
\hline EP & 0.210 & 0.503 & 1.000 \\
\hline
\end{tabular}

Compatibility is also positive correlated with job insecurity, turnover intention with values and employee performance. Complexity found to "be having high relationship with job insecurity and turnover intention, whereas, positively correlated with technological turnover intention and employee performance. Discussing job insecurity indicates positive correlation with employee performance. Attitude towards job insecurity has positive relationship with turnover intention but holds a strong positive relationship with employee performance.
Demographic Data and Return Percentages Satisfied with immediate boss and your work engagement

Strongly Agree

Neutral

Agree

Disagree Strongly Disagree

Table

\begin{tabular}{|c|c|c|}
\hline Work Engagement & Frequency & $\begin{array}{c}\text { Percentage } \\
\text { Results }\end{array}$ \\
\hline Strongly Agree & 25 & 16.67 \\
\hline Agree & 25 & 16.67 \\
\hline Neutral & 40 & 26.67 \\
\hline Disagree & 30 & 20.00 \\
\hline Strongly Disagree & 30 & 20.00 \\
\hline
\end{tabular}

Pie Graph

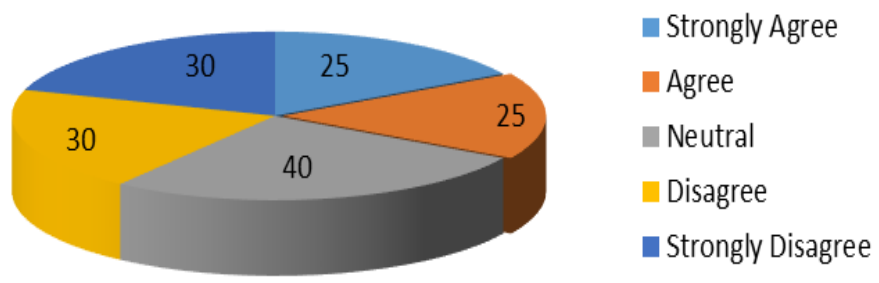

Bar Graph

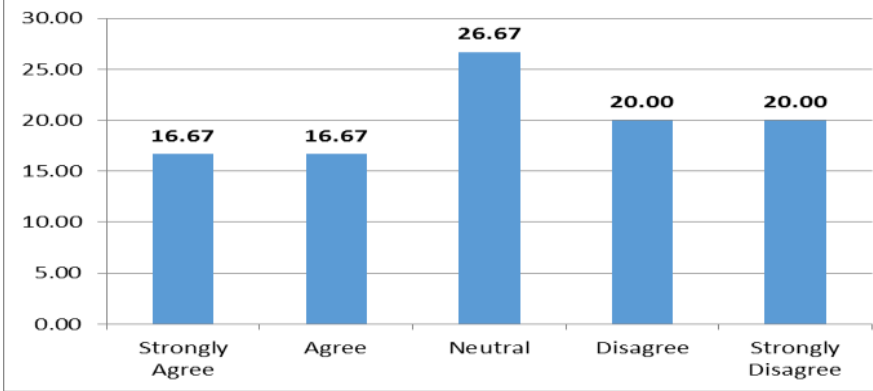

The above table and graphs are showing it is clear from the above results that most of the employees are valued.

\section{Descriptive Analysis}

\begin{tabular}{|c|c|c|c|c|c|}
\hline \multicolumn{7}{|c|}{ Turnover Intentions Table } & \\
\hline & Frequency & Percent & Valid Percent & Cumulative Percent & $\overline{\mathcal{X}}$ \\
\hline S.D & 13 & 6.7 & 6.7 & 6.7 & \\
\hline D & 25 & 14.0 & 14.0 & 20.7 & \\
\hline N & 32 & 19.3 & 19.3 & 40.0 & \multirow{3}{*}{3.45} \\
\hline A & 58 & 47.3 & 47.3 & 87.3 & \\
\hline S.A & 22 & 12.7 & 12.7 & 100.0 & \\
\hline Total & 150 & 100.0 & 100.0 & & \\
\hline
\end{tabular}


Figure
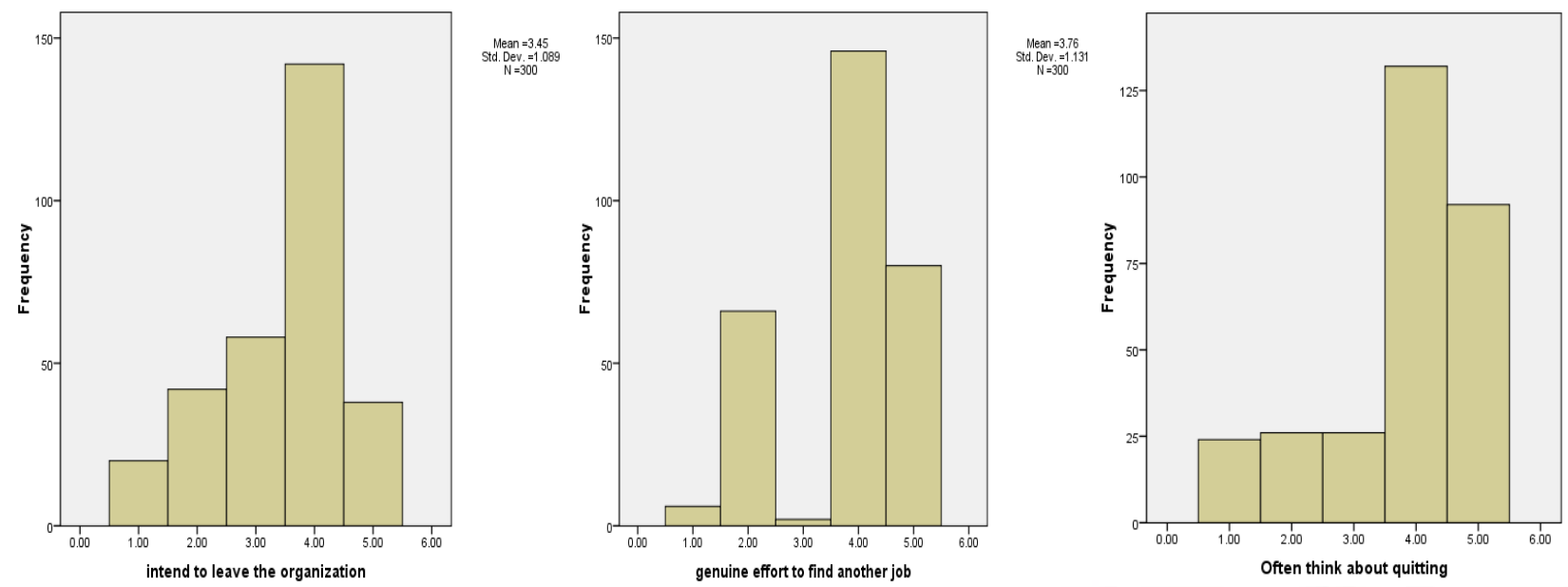

Turnover Intentions

Majority of $(60 \%)$ Respondents agree that they intend to leave the organization, secondly genuine effort to find another job was also agreed (75.4\%) and similarly, (74.7\%) respondents agree about the quitting of job. This indicates that most of employees are agree with turnover intentions in their work. The mean score for above said respective variables $(\bar{x}=$ $3.45,3.76 \& 3.81$ ) also shows the agreement among the respondents.
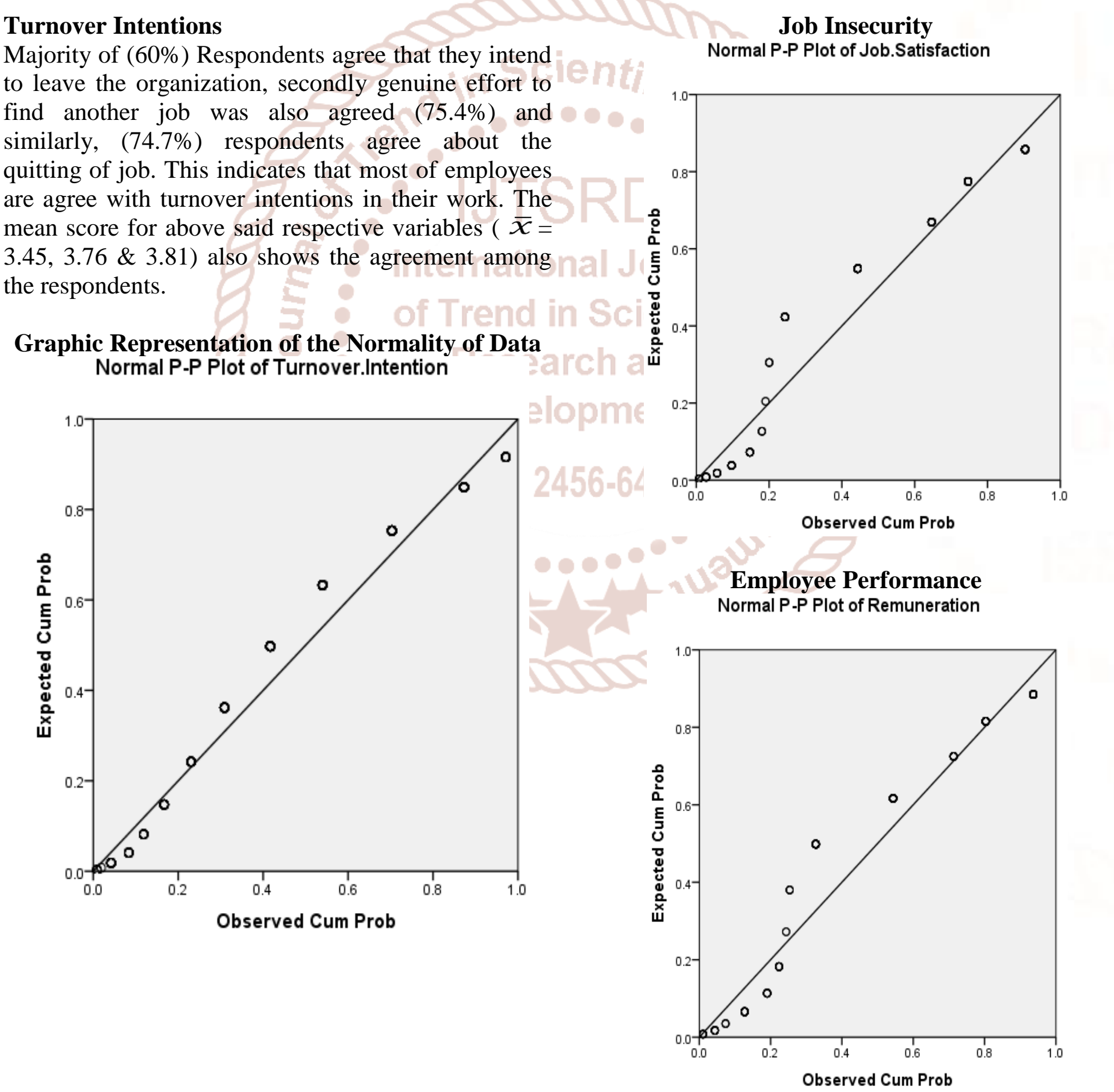


\section{Test of Association}

Table (H1)

\begin{tabular}{|c|c|c|c|c|}
\hline Variables & $\mathbf{N}$ & $d_{. f}$ & $X^{2}$ & P-Value \\
\hline Turnover Intention & 150 & 4 & 152.267 & $0.00022 *$ \\
\hline
\end{tabular}

According to the results of above mentioned test of association about the intention for leaving the job, the analysis of the data reflects that $\mathrm{P}=0.00022<.05$, hence $\mathrm{H} 1$ is not rejected.

\section{Table (H2)}

\begin{tabular}{|c|c|c|c|c|}
\hline Variables & N & $d_{\text {.f }}$ & $X^{2}$ & P-Value \\
\hline Job Insecurity & 150 & 4 & 235.200 & $0.00018^{*}$ \\
\hline
\end{tabular}

The Chi-Square analysis about search of another job, the analysis of the data represents that $\mathrm{P}=0.00018<0.5$, hence $\mathrm{H} 2$ is not rejected.

Table (H3)

\begin{tabular}{|c|c|c|c|c|}
\hline Variables & $\mathbf{N}$ & $d_{\text {.f }}$ & $X^{2}$ & P-Value \\
\hline $\begin{array}{c}\text { Employee } \\
\text { Performance }\end{array}$ & 150 & 4 & 163.600 & $0.00033^{*}$ \\
\hline
\end{tabular}

The results of test association regarding quitting from job, the analysis of the data shows that $\mathrm{P}=0.00033<.05$, hence $\mathrm{H} 3$ is not rejected.

\section{Discussions \\ Major findings}

Most of the researchers agree with that job insecurity affect the employee performance. Study examined the effect of job insecurity on employee performance an turnover intention by collecting the data from the employees of the organization. The present study of the job insecurity for employee performance adds particular value in Pharma sector of Lahore Multan and Karachi. Growth in Pharma industry is getting increase day by day. Further, study also adds value to review the policies regarding employee to increase their performance and turnover intention. We conduct this study to highlight the issues of job insecurity which affecting the employee performance on large scale and how it leads to the negative response in turnover.

Job insecurity has psychological effect on the employee. Employee has feared to lose his job in near future that's why he does not work with full devotion. Job insecurity also has negative impact of health on employee. Employee feels intense and his fear of losing job leads to hypertension and anxiety. Most of the Pharma employee has health issues like anxiety hypertension and obesity. Sturdy exists how job insecurity affects employee performance. This study contributes the social cognitive theory by empirically establishing a link among job insecurity and employee performance this research also indicates the link between employee performance and turnover intention. This research also tells us how job insecurity effect and employee performance effect turnover intention. Our major finding is that job insecurity manipulated employee performance and turnover intention.

Organization should take action and make policies which assure the employee about their job security, that kind of policies could enhance the employee performance and also affect the turnover intention. Organization should have to change their reward and punishment system. For examples, seniors of the organization should have to build high level of trust among their employees if the organization want to boost up employee performance they have to revise their reward and punishment policies on urgent basis.

\section{Theoretical Contribution}

Jo insecurity reduced work attitude which leads to poor performance of the employee. Study oppose job insecurity have direct effect on employee performance and turnover intention. Many theorists assume negative effect on employee performance but it also have positive effect because due to job insecurity employee have fear to lose his job and work with full attention. Organization should have to motivate their employees by increasing their reward system and motivate their employees to remove fear from employee mind. Job insecurity is a big challenge if researcher only assumes negative effect of job insecurity in theories they use only underspecified model which unable to elaborate the real effect of job insecurity on employee performance.

\section{Practical Implications}

Study has many important implications for the Organization to increase their employee performance. Employee feels fear in the field to lose his job, which increases their stress and reduces their intention in the job. They also feel insecure to miss their targets, because they think that if they lose their target they will lose their job and they do unethical sales to save their jobs. Due to strict tracing system they are always in hustle and think their basic human rights are overlooked. Organization should reconcile their policies and parameter for cheek and balance. 


\section{Limitations and Future Research}

Like every experimental study have some limitations. First, this study investigates the effect of job insecurity on employee performance and turnover intention. in this study role of family and social circle are not investigated. Future study could light upon understanding and their effect on performance and job insecurity. Sample size is not large due to the shortage of time, therefore, present result considers limited to the sample size and population which used in the study, and future research should conduct by collecting data from different population by using large sample size. Focus of the study is on job insecurity and employee performance further research could examine how turnover intension effected.

It is one of the limitations of our research that we relied on the goodwill and assessment of the employee and procedural justice to their work. Future research could use different tools to measure which support multiple techniques to examine the group level and individual factors on turnover intention.

\section{Conclusion}

Study able to compel that, job insecurity has effect on employee performance which also manipulates turnover intention. Present study adds further practical and theoretical knowledge to literature by mark how different aspect contributes to employee performance and turnover intention to vitalize to insecurity. This study base on concept that, the job insecurity neither are purely negative effect on employee performance nor positive. Rather, job insecurity is a stoppage and challenge stressor. Job insecurity can understand as a significant difference between what offer by the employers and what employees hope for that leads to reducing their struggle and so it also reduces employee performance.

At that time job insecurity also provoke employee to boost the effort because increase in performance may be perceived as a security against being terminated. Study supports both effects which pick up from study model. Therefore, the managers who think that increase in job insecurity is a beneficial strategy should advise not to ignore negative effect of job insecurity on employee performance.

\section{References}

1. Ashforth. (2008). Identification in organizations: An examination of four fundamental questions. Journal of Management .
2. Attridge. (2009). Measuring and managing employee work engagement: a review of the research and business literature. Journal of Workplace Behavioral Health .

3. Bakker. (2008). work engagement an emerging concept in occupational health psychology. Work \& Stress, .

4. Bertelli. (2007). Determinants of bureaucratic turnover intention: Evidence from the Department of the Treasury. Journal of Public Administration Research and Theory .

5. Bluedorn. (1997). The Theories of Turnover: Causes, Effects, and Meaning. JAI Press, Greenich .

6. Bono. (2017). The role of supervision and leadership. Journal of Applied Psychology, .

7. Borman. (2001). Expanding the criterion domain to include elements of contextual performance. personal selection in Organizations, Jossey-Bass, San Francisco, .

8. Bormen. (2013). Effects of ratee task performance and. Journal of Applied .

9. Brown. (1996). A new look at psychological climate and its relationship to job involvement,effort, and performance. Journal of Applied Psychology.

10. Burke. (2007). Mergers and acquisitions, downsizing, and privatization: a North American perspective. The New Organizational Reality: Downsizing, Restructuring, and Revitalization .

11. Callea. (2012). Temporary employment in Italy and its consequences on gender. Gender in Management: An International Journal .

12. Cambell. (2015). journal of phsycology .

13. Campbell. (2016). Modeling the performance prediction problem in industrial and organizational psychology. Handbook of Industrial and Organizational Psychology .

14. Cao. (2013). "Does total rewards reduce the core employees' turnover intention? International Journal of Business Management .

15. Cardy. (2004). Concepts, Skills, and Exercises, M.E. $\quad$ Sharpe,Armonk,NY. Performance management . 
16. Chan. (2011). Modelling job stress as a mediating role in predicting turnover intention. Service Industries Journal .

17. Chen. (2011). Modelling job stress as a mediating role in predicting turnover intention. Service Industries Journal .

18. Cheng. (2008). Who suffers more from job insecurity? A meta-analytic review. Applied Psychology: An International Review .

19. Collins. (2006). "Knowledge exchange and combination: the role of human resource practices in the performance of high-technology firms",. Academy of Management journal .

20. Cool. (2017). European managment journal.

21. Dalal. (2005). "A meta-analysis of the relationship between organizational citizenship behavior and counterproductive work behavior. Journal of Applied Psychology .

22. Davies. (2016). Using social exchange theory to predict the effects of HRM practice on employee outcomes. Public Management Review.

23. Delery. (2001). Modes of theorizing in strategic human resources management: test IC of universalistic, contingency, and configurational performance predictions. Academy of Management Journal .

24. Detert. (2010). Speaking up to higher ups: How supervisor and skip-level leaders |influence employee voice. Organization Science.

25. Develles. (2016). Using multi variance statistics.

26. Dysvik. (2013). Perceived job autonomy and turnover intention: The moderating role of perceived supervisor support. European Journal of Work and Organizational Psychology.

27. Eden. (1993). Self-efficacy training to speed reemployment: Helping people to help themselves. Journal of Applied Psychology .

28. ESC. (2007). Annual Report on the Socioeconomic and Employment .

29. Eurobarometer. (2006). "European employment and social policy",. Special Eurobarometer.

30. Ferrie. (1993). Labour market status, insecurity and health. Journal of Health Psychology, .

31. Gran. (2015). Giving time, time after time: Work design and sustained employee participation in corporate volunteering. Academy of management review.

32. Grant. (2012). Giving time, time after time: Work design and sustained employee participation in corporate volunteering. Academy of management review.

33. Greenhalgh. (1998). "Job insecurity: towards conceptual clarity. Academy of Management Review, .

34. Hackman. (2011). Employee reactions to job characteristics. Journal of Applied Psychology .

35. Haines. (2010). The influence of human resource management practices on employee voluntary turnover rates in the Canadian non governmental sector. Industrial and Labor Relations Review .

36. Harrison. (2006). "How important are job attitudes? Meta-analytic comparisons of integrative behavioural outcomes and time sequences. Academy of Management Journal .

37. Hayes. (2014). British journal of mathematical and statistical psycology.

38. Hillman. (2008). Directors' multiple identities, identification, and board monitoring and resource provision. Organization science .

39. Horner. (1991). An evaluation of precursors of hospital employee turnover. Journal of Applied Psychology .

40. ISSP. (2005). Work Orientations Survey .

41. Joelson. (2005). The psychological meaning of job insecurity and job loss: results of a longitudinal study. social science and medicine .

42. Judge. (2017). Five-factor model of personality and job satisfaction: A metaanalysis. Journal of Applied Psychology.

43. Jung. (2012). Causes of newspaper firm employee burnout in Korea and its impact on organizational commitment and turnover intention. International Journal of Human Resource Management .

44. Kanungo. (2010). Measurement of job and work involvement. Journal of Applied Psychology .

45. Kim. (2017). "An examination of leader-member exchange (LMX) agreement between employees and their supervisors and its influence on work outcomes. Journal of Hospitality Marketing and Management . 
46. Korff. (2015). The impact of humanitarian context conditions and individual characteristics on aid worker retention. Disasters .

47. Lee. (1997). "Content, causes, and consequences of job insecurity: a theory-based measure and substantive test". Academy of Management Journal .

48. Lentz. (2009). Industrial and Organizational Psychology phenomenon. Journal of Applied Psychology.

49. Locke. (2016). The nature and causes of job satisfaction. In M. D. Dunnette (Ed.),. Handbook of industrial and organizational psychology .

50. Macdonald. (2003). Teacher attrition: a review of literature. Teaching and Teacher Education .

51. Macky. (2007). The relationship between "highperformance work practices" and employee attitudes: An investigation of additive and interaction effects. international Journal of Human Resource Management .

52. Mitchell. (2010). The managerial relevance of ethical efficacy.In M. Schminke (Ed.), Managerial ethics. Managing the psychology of morality.

53. Mobley. (1989). "An evaluation of precursors of hospital employee turnover. Journal of Applied Psychology.

54. Mone. (2010). Employee Engagement Through Effective Performance management. A Practical Guide for Managers, Routledge .

55. Morrow. (2012). "Influencing organizational commitment through office redesign. Journal of Vocational Behavior .

56. Motowidlo. (2012). Evidence that task performance should be. Journal of Applied Psychology.

57. Moynihan. (2011). Explaining turnover intention in state government:Examining the roles of gender, life cycle, and loyalty. Review of Public Personnel Administration .

58. Nunnally. (2017). Journal of business research.

59. Oldham. (2016). Conditions under which employees respond positively to enriched work. Journal of Applied Psychology, .

60. Pfeffer. (2006). Hard Facts, Dangerous HalfTruths, and Absolute Nonsense Profiting from
Evidence-Based Management. Harvard Business School Press, Boston .

61. Piccoli. (2017). Job insecurity and discretionary behaviours: social exchange perspective versus group value model",. Scandinavian Journal of Psychology .

62. Ross. (2017). Using multy variate statistics.

63. Rub. (2004). "Job stress, job performance, and social support among hospital nurses",. Journal of Nursing Scholarship, .

64. Russell. (2004). Shorter can also be better: The abridged Job in General Scale. Educational and Psychological Measurement .

65. Schmidt. (2014). Uncertainty in the workplace: Examining role ambiguity and role conflict, and their link to depression-a meta-analysis. European Journal of Work and Organizational Psychology .

66. Shaffer. (2001). Struggling for balance amid turbulence on international assignments: workfamily conflict, support and commitment", journal of managment .

67. Shoss. (2017). Job insecurity: an integrative review and agenda for future research", . journal of Management .

68. Smith. (2017). journal of organizational change managment.

69. Steel. (1994). A review and meta-analysis of research on the relationship between behavioral intentions and employee turnover. Journal of Applied Psychology,.

70. Steers. (2013). Motivation and work behavior. NEW York: McGraw-Hill.

71. Sverk. (2008). "Job insecurity - a literature review",Saltsa. National Institute for Working Life, Stockholm .

72. Sverke. (2004). Job Insecurity and union membership. European Unions in theWake of Flexible Production, P.I.E. Peter Lang, Brussels.

73. Svrek. (2002). No security: a meta-analysis and review of job insecurity and its consequences. Journal of Occupational Health Psychology, .

74. Telford. (2007). The international humanitarian system andthe 2004 Indian Ocean earthquake and tsunamis. Disasters .

75. Tett. (2009). "Job satisfaction, organizational commitment, turnover intention, and turnover: 
path analysis based on meta-analytic findings. personnal Psychology.

76. Trevor. (2010). "Keeping your headcount when all about you are losing theirs: downsizing, voluntary turnover rates, and the moderating role of $\mathrm{HR}$ practices. Academy of Management Journal .

77. Ubeda. (2013). "Does training influence organisational performance? Analysis of the Spanish hotel sector",. European Journal of training and development .

78. Van. (2004). Group belongingness and procedural justice: social inclusion and exclusion by peers affects the psychology of voice",. journal of Personality and Social Psychology .

79. Vander. (2014). "Perceived control and psychological contract breach as explanations of the relationships between job insecurity, job strain and coping reactions: towards a theoretical integration. stress and health.

80. Vogus. (2011). Establishing and extending the foundations of highly reliable performance. In: Cameron KS and Spreitzer (eds). The Oxford Handbook of Positive Organizational Scholarship. New York: Oxford University.
81. Vujicic. (2015). The relationship between job security, job satisfaction, and organizational commitment among employees in the tourism sector in novi sad. Economic and Industrial Democracy .

82. Wang. (2014). The effect of role ambiguity on task performance through selfefficacy A contingency perspective. IEEE Transactions on Engineering Management .

83. Williams. (2009). Using social exchange theory to predict the effects of HRM practice on employee outcomes. public managment review.

84. Winter. (2000). The quantitaive report.

85. Witte, D. (2015). "Job insecurity, health and wellbeing", in Vuori, J.,Blonk, R. and Price. Sustainable Working Lives: Managing Work Transitions and Health Throughout the Life Course, Springer .

86. Youngblood. (1993). A longitudinal analysis of the turnover process. Journal of Applied Psychology, .

87. Yousaf. (2015). Organizational/occupational commitment and organizational/occupational turnover intentions: A happy marriage? personnel review. 